\title{
Community-acquired diarrhea among children and adults in urban settings in Senegal: clinical, epidemiological and microbiological aspects
}

\author{
Bissoume Sambe-Ba ${ }^{1 *}$, Emmanuelle Espié ${ }^{2}$, Mamadou Elimane Faye ${ }^{1}$, Lassina Gadi Timbiné ${ }^{1}$ \\ Mbacké Sembene $e^{3}$ and Amy Gassama-Sow ${ }^{1,3}$
}

\begin{abstract}
Background: Only limited data are available relating to the etiology of diarrhea in children and adults in Senegal. The aim of this prospective study was to describe the epidemiology and etiology of community-acquired diarrheal infections in children and adults living in urban settings.

Methods: A prospective study was carried out from March 2009 to December 2010, in the urban region of Dakar, Senegal. Patients with acute diarrhea were enrolled, interviewed to collect their clinical history, and their stools were tested for bacteria, virus and parasites.

Results: A total of 223 patients (including 112 children younger than five years old) with diarrhea were included. At least one enteropathogen was detected in $81 \%(180 / 223)$ of the patients: $29 \%(64 / 223)$ had bacterial infections (mainly diarrheagenic E. coli and Shigella spp), 21\% (39/185) viral infections (mainly rotavirus) and 14\% (31/223) parasitic infections. Co-infection was identified in 17.8\% (32/180) of the patients. Viral infection was significantly more frequent in children under five years old during the dry season. Bacteria and parasites were equally frequent in all age groups. There was a seasonal variation of bacterial infections during the study period, with a higher proportion of infections being bacterial, and due to Salmonella spp. in particular, during the rainy season.

Conclusion: Our study suggests that in urban settings in Senegal, rotavirus is the principal cause of pediatric diarrhea during the dry season and that the proportion of bacterial infections seems to be higher during the rainy season. Further work is needed to document the burden of diarrheal diseases in sub-Saharan urban communities and to identify risk factors, including those linked to the rapid and unplanned urbanization in Africa.
\end{abstract}

Keywords: Diarrhea, Bacteria, Virus, Parasite, Children, Adults, sub-Saharan Africa

\section{Background}

Diarrheal diseases remain one of the principal causes of childhood mortality and morbidity in low income countries despite significant progress in our understanding of the pathogenesis of these diseases and in their management. According to the World Health Organization, diarrheal disease is the second leading cause of death in children under five years old worldwide, and is responsible for 1.5 million child deaths every year. The risk of

\footnotetext{
* Correspondence: bsambe@pasteur.sn

${ }^{1}$ Experimental Bacteriology Unit, Pasteur Institute of Dakar, 36 avenue Pasteur, BP 220 Dakar, Senegal

Full list of author information is available at the end of the article
}

contracting diarrheal diseases is currently 5 -fold higher in sub-Saharan Africa than in industrialized countries [1].

In sub-Saharan Africa, and particularly in Senegal, urban migration has increased over the last 30 years, resulting in a disorganized urban landscape where populations live in crowded housing conditions. This rapid expansion of cities, with the creation of urban slums, the lack of or inadequate safe water supply, inadequate drainage and sewage networks, and absence of sanitation and solid waste removal, has increased the risk of infectious diseases including diarrheal diseases and respiratory infections [2].

Most of the studies of diarrheal disease in sub-Saharan Africa over the last 20 years have focused on children

\section{Biomed Central}


under 5 years old [3-7] and rural settings [4-6,8]. Consequently, only limited information about the epidemiology and etiology of diarrheal infections in adults in developing countries is available [8-10]. Although adults are less likely to contract diarrhea, and when they do, it is unlikely to be life threatening, adults contribute to the transmission of enteric pathogens to susceptible patients, and in particular children and older people.

A wide range of bacteria, viruses, and parasites can cause diarrhea [11]. The features and the patterns of isolation of etiologic agents vary from place to place depending on the local climate and geography, and on socioeconomic factors [12]. Data on the epidemiology and etiology of diarrhea would be valuable for planning and implementing control strategies to reduce diarrhea-caused morbidity and mortality and for establishing recommendations about appropriate antimicrobial therapy in a country.

The aims of this prospective study were to describe the etiology of community-acquired diarrhea in children and adults living in a Senegalese urban setting and to assess the clinical and epidemiological characteristics of the disease.

\section{Methods}

Study area, target population and samples collection

The study was conducted between March 2009 and December 2010 in the urban region of Dakar, including the city of Dakar, the capital of Senegal, and two suburb cities (Pikine, Guediawaye). This region is located in the central western part of the country and covers $550 \mathrm{~km}^{2}$ ( $0.3 \%$ of the total area of the country); it has an estimated population of 3.2 million inhabitants $(25 \%$ of the total population) (Figure 1). The climate is Sahelian, with a rainy season from July to October and a dry season from November to June.

Patients were recruited at the outpatient departments of eight major health centers in the three cities. The enrollment criteria were diarrhea (three or more loose or liquid stools within $24 \mathrm{~h}$ during the month before the visit) and no anti-infective therapy during the previous week. Patients who fulfilled these criteria were invited to participate. After providing informed consent the patient was assessed clinically by a physician and the patient, or if a child, a parent, was interviewed. The following clinical, demographic and epidemiological data were recorded: age, sex, place of residence, weight, height, symptoms such as fever $\left(\geq 38^{\circ} \mathrm{C}\right)$, nausea, vomiting, abdominal pain, dehydration status (according to skin turgor and capillary refill), number of loose stools during the past $24 \mathrm{~h}$, and whether the patient had been using antibiotic, antiparasitic, antipyretic or analgesic medication. For each patient, a stool sample was collected in sterile plastic container and immediately transported to the laboratory at the Pasteur Institute of Dakar.



Figure 1 Map of Senegal and location of the three studied areas: Dakar, Pikine and Guediawaye. 


\section{Laboratory methods}

Fresh stool samples were processed and analyzed for enteric pathogens on the day of collection. For detection of bacterial pathogens (Salmonella spp, Shigella spp, Campylobacter spp, diarrheagenic E. coli, Vibrio spp), stools were cultured on agar plates with suitable selective media at $37^{\circ} \mathrm{C}$ and $42^{\circ} \mathrm{C}$ (for thermophilic Campylobacter) for periods appropriate for each microorganism. Biochemical tests and antiserum agglutination were used to identify selected isolated colonies. Unusual bacteria and E. coli were considered to be the sole etiologic agent of diarrhea when they were obtained as a pure culture on nonselective, solid, bromocresol-purple medium and when a significant virulence gene was identified in at least three of five colonies tested. PCR was used to detect genes coding for virulence factors (eagg, eae, bfp, ipah, Stx1, Stx2, ST, $L T)$ as a test for diarrheagenic E. coli [13].

The stool specimens collected were examined microscopically for intestinal parasites (trophozoites, eggs), after staining with merthiolate-iodine-formaldehyde solution. Coccidia were detected with Kinyoun dye and Microsporidia with a modified trichrome dye with a high concentration of chromotrope $2 \mathrm{R}$.

A rapid test, based on immunochromatography, was used to detect both Rotavirus and Adenovirus (VIKIA ${ }^{\circ}$ Rota-Adeno, bioMérieux) and PCR was used to detect Calicivirus and Enterovirus [14].

The infection was scored as a confirmed bacterial infection if one of Salmonella spp, Shigella spp, Campylobacter spp, diarrheagenic E. coli or Vibrio spp was isolated; as a confirmed viral infection if a rapid test for Rotavirus and Adenovirus, or a PCR for Calicivirus and Enterovirus was positive; and as a confirmed parasite infestation if Giardia lamblia, Trichomonas intestinalis or Cryptosporidium spp was detected.

\section{Statistical analysis}

$\mathrm{R}$ software was used for statistical analysis [15]. The chisquare test and the Fisher exact test were used for comparison of categorical variables and the Mann-Whitney $U$ test was used for continuous variables. A p-value $<0.05$ was considered statistically significant.

Patients with confirmed infection were compared to patients without confirmed infection in terms of gender, age group ( $\leq 5$ years, $6-15$ years and $>15$ years), season of diarrhea occurrence (dry and rainy season) and clinical symptoms (including hospitalization).

\section{Ethical aspects}

The study protocol was approved by the national ethics committee for research in health (Ministry of Health of Senegal). Informed written consent was obtained from the patient, or the parent if the patient was a child, before inclusion in the study.

\section{Results}

From March 2009 to December, 2010, 223 patients who met the enrollment criteria were included in the study: $103(46.2 \%)$ in Pikine, 66 (29.6\%) in Dakar and 54 (24.2\%) in Guediawaye; 44 patients (19\%) eligible for the study were excluded because they reported previous intake of antibiotic or antiparasitic drugs.

\section{Epidemiological and clinical characteristics}

In the study population, $46.2 \%$ (103/223) were female, the median age was 5 years [IQR, 2-27] and 50.2\% (112/ 223) of the patients were under five years old (Table 1). Almost all the patients were inhabitants of the study area $(98 \% ; 218 / 223)$, and the remaining five patients were living in the study area at the onset of diarrhea although their permanent residence was elsewhere.

As reported by patients, the mean duration of diarrheal symptoms before visiting the health center was

Table 1 Epidemiological and clinical characteristics of the 223 patients with diarrhea, 2009-2010, urban setting, Senegal



${ }^{1}$ Mean and range; ${ }^{2}$ Only 185 samples were tested for enteric viruses. 
3.7 days [range, 0-28 days]. The symptoms reported most frequently were abdominal pain $(72.6 \%, 156 / 215)$, weakness (41.9\%, 85/203), and vomiting (36.5\%, 80/219). On examination, $25.8 \%(54 / 209)$ of the patients were found to be febrile and $16.3 \%$ (34/209) showed dehydration. Direct observation showed presence of mucus in $37.2 \%$ of the stools (83/223), and blood in $13.4 \%$ (30/223). Persistent diarrhea (duration $>14$ days) was reported for $3.8 \%(8 / 223)$ of patients, including six children less than five years old. Twenty-nine of the 223 patients (13\%) were hospitalized; no deaths were reported.

\section{Identification of enteric pathogens}

No pathogen was identified or isolated from 43 (19.3\%) of the 223 patients. A total of 257 potential enteric pathogens were isolated from the other 180 stool samples: 115 (44.7\%) were parasites, 87 (33.8\%) were bacteria and 54 (21.0\%) were viruses (Table 2).

Shigella spp and pathogenic E. coli were the most frequently isolated bacteria $(32.2 \%, 28 / 87)$; the unusual or opportunistic bacteria Citrobacter freundii, Klebsiella spp, Morganella morganii, Aeromonas spp, Providencia rettgeri, and Enterobacter cloacae were also found (20.7\%; 18/87). Twenty-two (78.6\%) of the 28 strains of Shigella spp were Shigella flexneri. Twenty-one (75\%) of the 28 pathogenic E. coli were EPEC and EAEC, ETEC and VTEC were also found. There were 12 Salmonella enterica isolates including the following serotypes: Enteritidis ( $\mathrm{n}=3)$, Typhimurium (2), Typhi (2), Hillingdon (1), Poona (1), Putten (1), Nima (1), and Somone (1). Ascaris lumbricoides $(38 / 115,31.4 \%)$ was the most frequently identified parasite, and rotavirus $(50.0 \%, 27 / 54)$ the most frequent enteric virus.

Thirty-two specimens yielded more than 1 potential enteric pathogen: these co-infections included parasites and bacteria $(n=8)$, parasites and virus $(n=3)$, and bacteria and viruses $(n=5)$, but also two different viruses $(\mathrm{n}=14)$, and two different bacteria $(\mathrm{n}=2)$. The pathogens most frequently involved in co-infection were pathogenic E. coli for bacteria, Trichomonas intestinalis for parasites and rotavirus for viruses. In one 22 monthold patient, co-infection with EAEC-Giardia lambiaCalicivirus was identified.

\section{Confirmed infected patients and clinical and epidemiological features}

No statistically significant association was found between parasitic infection and epidemiological or clinical characteristics.

Bacterial infection occurred more frequently during the rainy season ( $35.7 \%$ vs. $16.2 \%, \mathrm{p}=0.002)$ (Table 3 ). Salmonella infection occurred more frequently during the rainy season $(7.5 \%$ vs. $1.2 \%, \mathrm{p}=0.03)$. Shigella species were significantly more frequently isolated from patients
Table 2 Frequency and age distribution of enteric pathogens isolated from stools samples of the $\mathbf{2 2 3}$ patients with diarrhea, 2009-2010, urban setting, Senegal

\begin{tabular}{|c|c|c|c|}
\hline \multirow[t]{2}{*}{ Enteric pathogens } & \multicolumn{3}{|c|}{ No. of enteric pathogens identified (\%) } \\
\hline & All age & $\leq 5$ year & $>15$ years \\
\hline Total (N) no. of pathogens ${ }^{1}$ & 257 & 141 & 78 \\
\hline Parasites & $115(44.7)$ & $51(36.2)$ & $47(60.2)$ \\
\hline Ascaris lumbricoides & $38(14.8)$ & 12 & 23 \\
\hline Enterobius vermicularis & $26(10.1)$ & 21 & 0 \\
\hline Schistosoma mansoni & $16(6.2)$ & 3 & 13 \\
\hline Trichomonas intestinalis & $12(4.7)$ & 3 & 5 \\
\hline Cryptosporidium spp & $11(4.3)$ & 5 & 6 \\
\hline Giardia lambia & $8(3.1)$ & 5 & 0 \\
\hline Microsporidium spp & $4(1.6)$ & 2 & 0 \\
\hline Bacteria & $87(33.8)$ & $39(27.6)$ & $31(39.7)$ \\
\hline Shigella spp & $28(10.9)$ & 8 & 17 \\
\hline Enteropathogenic E. coli & $28(10.9)$ & 15 & 3 \\
\hline EAEC (eagg) & 3 & 3 & 0 \\
\hline $\operatorname{ETEC}(L T, S T)$ & 3 & 3 & 0 \\
\hline $\operatorname{EPEC}(e a e, b f p)$ & 21 & 9 & 3 \\
\hline VTEC (st×2) & 1 & 0 & 0 \\
\hline Salmonella spp & $12(4.7)$ & 6 & 4 \\
\hline Citrobacter freundii & $7(2.7)$ & 3 & 4 \\
\hline Klebsiella spp & $5(2.7)$ & 1 & 3 \\
\hline Morganella morganii & $3(1.9)$ & 2 & 0 \\
\hline Campylobacter spp & $1(0.4)$ & 1 & 0 \\
\hline Aeromonas spp & $1(0.4)$ & 1 & 0 \\
\hline Others $^{2}$ & $2(0.8)$ & 2 & 0 \\
\hline Viruses & $54(21.0)$ & $51(36.2)$ & 0 \\
\hline Rotavirus & $27(10.5)$ & 26 & - \\
\hline Adenovirus & $17(6.6)$ & 17 & - \\
\hline Calicivirus & $7(2.7)$ & 6 & - \\
\hline Enterovirus & $3(1.2)$ & 2 & - \\
\hline
\end{tabular}

${ }^{1}$ Stools samples from some patients yielded $>1$ enteric pathogen.

${ }^{2}$ Providencia rettgeri, Enterobacter cloacae.

over 15 years old $(70.8 \%$ vs. $27.5 \%, \mathrm{p}<0.001)$ and from cases with bloody stools ( $\mathrm{p}<0.001$ ).

Viral infection was significantly associated with age: a greater proportion of children younger than five years old than older patients were infected with virus (33\% vs. $1.8 \%, \mathrm{p}<0.001)$. A significantly greater proportion of infections during the dry season than rainy season were viral $(31.8 \%$ vs. $15.2 \%, \mathrm{p}<0.01)$.

\section{Discussion}

To our knowledge, this study is the first study in a subSaharan country, including Senegal, investigating the etiology and clinical and epidemiological characteristics of 
Table 3 Characteristics ${ }^{1}$ of the study participants in relation to confirmed infection with the different enteropathogens

\begin{tabular}{|c|c|c|c|c|c|c|c|}
\hline & No & Bacteria, n (\%) & p-value & Virus, n (\%) & p-value & Parasite, n (\%) & p-value \\
\hline \multicolumn{8}{|l|}{ Gender } \\
\hline Male & 120 & $39(32.5)$ & 0.18 & $23(19.2)$ & 0.48 & 19 (15.8) & 0.37 \\
\hline Female & 103 & $25(24.3)$ & & $16(15.5)$ & & $12(11.6)$ & \\
\hline \multicolumn{8}{|l|}{ Age range } \\
\hline$\leq 5$ years & 112 & $27(24.1)$ & 0.19 & $37(33.0)$ & $<0.01$ & $13(11.6)$ & 0.28 \\
\hline $6-15$ years & 30 & $13(43.3)$ & & $2(6.7)$ & & $7(23.3)$ & \\
\hline$>15$ years & 81 & $24(29.6)$ & & 0 & & $11(13.6)$ & \\
\hline \multicolumn{8}{|l|}{ Season } \\
\hline Dry & 80 & $13(16.2)$ & 0.002 & $21(26.2)$ & 0.01 & $10(12.5)$ & 0.65 \\
\hline Raining & 143 & $51(35.7)$ & & $18(12.6)$ & & $21(14.7)$ & \\
\hline
\end{tabular}

${ }^{1}$ No statistically significant association was found between any confirmed infection and clinical characteristics.

diarrhea in patients, both children and adults, living in urban settings.

At least one enteric pathogen was isolated from stools from $81 \%$ of patients with diarrhea. The enteric pathogens isolated from these cases of diarrhea were most frequently bacteria (29\%), although both virus (21\%) and parasites (14\%) were also isolated from many cases. The corresponding values for children younger than five years old were similar except that viral infection was more frequent. These values are higher than those reported by studies conducted in rural African areas [3-5] and urban African settings [16].

The etiological agent was most frequently a bacterium in our study, with diarrheagenic E. coli and Shigella spp being predominant. These findings are consistent with published results $[5,7,8,16]$. However, in contrast with previous studies [3,5], the proportion of bacterial infections seemed to be higher during the rainy season. In the Dakar region, the rainy season includes the warmest months and the period of floods. Flooding is responsible for poor sanitation and increases human contact with wastewater; it is also associated with cholera outbreaks [17]. Therefore, it is likely that a large number of diarrheal episodes during the rainy season results from increased exposure to environmental pathogens and contaminated food. Only one isolate of VTEC and another of Campylobacter were isolated from children less than 15 years old during this study. This suggests that the occurrence of VTEC and Campylobacter infections in Senegal is similar to those described in Ghana and Tanzania [5,6], and lower than those observed in some other African countries (Kenya, Nigeria and Mozambique) $[4,7,18,19]$. Eighteen unusual or opportunistic bacteria were also isolated from patients with diarrhea. These findings are consistent with reports from studies in Burkina Faso [20] and in Senegal, of HIV-infected patients [9]. Unfortunately, no data was recorded about HIV status, co- morbidities or concomitant disease (e.g. malaria, acute respiratory infection or malnutrition).

Our study also showed that rotavirus and other virus seem to be significant pathogens among children younger than five years, especially among children younger than one year, confirming their role already described in the occurrence of pediatric diarrhea [21]. Furthermore, a higher frequency of viral infection was observed during the dry and cold period, thereby demonstrating what it's already observed in other sub-Saharan countries [3,5,6].

Parasites were detected in $14 \%$ of all patients and in $12 \%$ in children younger than five years. This proportion is higher in comparison to those described in studies conducted in other developing countries [4,6,22]. Schistosoma mansoni infection was detected mainly in adults. For these patients who reported a previous stay in the North of Senegal, the origin of the contamination was probably linked to their occupation (i.e. farmers) in the Senegal River Basin, which is known to be an endemic area for bilharzias [23], but no further investigation was carried out to confirm this hypothesis.

In this study, one third of the patients with diarrhea were found to have co-infections, involving more than one potential enteropathogen. In developing countries, it is not uncommon to isolate more than one enteric pathogen from the same patient. The prevalence of coinfection in our patients younger than five years old was higher than reported in Burkina Faso (10.0\%) [3] and Madagascar (22.8\%) [24]. The relative contributions of each individual enteropathogen to the clinical symptoms cannot be determined in such cases of co-infection. Indeed, the interpretation of data on co-infections is complicated because not all the potential enteropathogens detected necessarily contribute to the etiology of the patient's diarrheal disease. Due to the limited sample size and the study design, we were not able to analyze indicators of severe diarrhea in patients with co-infections 
(e.g., admission to an intensive care unit, or death) that would have prompted more extensive investigation.

Our study has several limitations, including the study design: the population included was not a random sample and of limited size. Stool samples from a comparable control population were not studied so the extent of asymptomatic carriage of enteropathogens cannot be evaluated. The absence of controls in this study prevents testing for associations between particular organisms and the occurrence of diarrhea. Our study describes the prevalence of diarrheal diseases among patients seeking care, and this may not represent the burden of disease in the general urban population. The population studied included three times as many children less than five years old than the general population [25], probably because the threshold for seeking care is lower for young children with diarrhea than for older patients. The small sample size was due, in part, to difficulties recruiting patients who met the inclusion criteria: about one fifth of patients were excluded because they reported having recently taken antibiotics or antiparasitic drugs.

\section{Conclusion}

This study suggests that in urban settings in Senegal, diarrheal infections are mainly associated with enteric bacteria display a marked seasonality, being most frequent during the rainy season. In children younger than five years old, viral infections, with rotavirus in particular, are predominant, and are more frequent during the dry season. The urban context with its particular living conditions (including uncontrolled expansion of urban slums and informal settlements, residential overcrowding, or environmental degradation) may explain these patterns.

Further studies, including more representative samples or with control group or both, are needed to determine the burden of diarrheal diseases in sub-Saharan urban communities. Such studies may identify specific risk factors linked to the rapid and unplanned urbanization in Africa.

\section{Competing interests}

The authors declare that they have no competing interest.

\section{Authors' contribution}

AGS designed the study. BSB was responsible for recruitment, interview of the patients, sample collection and transport to the laboratory. BSB, FME and TLG were in charge of laboratory procedures. EE did the statistical analysis. $B S B, E E$ and $A G S$ wrote the manuscript. All authors read and approved the final manuscript.

\section{Acknowledgements}

We thank the Senegalese Ministry of Health, and Dr Marie Khémess Ngom Ndiaye (Health district of Dakar, Dr Ndeye Maguette Ndiaye (Health district of Mbao), Dr Alioune Gaye (Health district of Guediawaye), Dr Abdou karim Diop (Health district of Pikine).
Financial support was provided by a grant from the Senegalese Ministry of Scientific Research [FIRST, Fonds d'impulsion de la recherche scientifique et technique].

\section{Author details}

'Experimental Bacteriology Unit, Pasteur Institute of Dakar, 36 avenue Pasteur, BP 220 Dakar, Senegal. ${ }^{2}$ Epidemiology Unit, Pasteur Institute of Dakar, Dakar, Senegal. ${ }^{3}$ University Cheikh Anta Diop, Dakar, Senegal.

Received: 29 April 2013 Accepted: 2 December 2013

Published: 9 December 2013

\section{References}

1. Schiller LR: Management of diarrhea in clinical practice: strategies for primary care physicians. Rev Gastroenterol Disord 2007, 7:27-38.

2. Patel RB, Burke TF: Urbanization, an emerging humanitarian disaster. N Engl J Med 2009, 361(8):741-3.

3. Nitiema LW, Nordgren J, Ouermi D, Dianou D, Traore AS, Svensson L, Simpore J: Burden of rotavirus and other enteropathogens among children with diarrhea in Burkina Faso. Int J Infect Dis 2011, 15(9):e646-52.

4. Mandomando IM, Macete EV, Ruiz J, Sanz S, Abacassamo F, Vallès X, Sacarlal J, Navia MM, Vila J, Alonso PL, Gascon J: Etiology of diarrhea in children younger than 5 years of age admitted in a rural hospital of southern Mozambique. Erratum in: Am J Trop Med Hyg 2008, 79(1):140.

5. Vargas M, Gascon J, Casals C, Schellenberg D, Urassa H, Kahigwa E, Ruiz J, Vila J: Etiology of diarrhea in children less than five years of age in Ifakara, Tanzania. Am J Trop Med Hyg 2004, 70(5):536-9.

6. Reither K, Ignatius R, Weitzel T, Seidu-Korkor A, Anyidoho L, Saad E, Djie-Maletz A, Ziniel P, Amoo-Sakyi F, Danikuu F, Danour S, Otchwemah RN, Schreier E, Bienzle U, Stark K, Mockenhaupt FP: Acute childhood diarrhoea in northern Ghana: epidemiological, clinical and microbiological characteristics. BMC Infect Dis 2007, 7:104.

7. Okeke IN, Lamikanra A, Steinrück H, Kaper JB: Characterization of Escherichia coli strains from cases of childhood diarrhea in provincial southwestern Nigeria. J Clin Microbio/ 2000, 38(1):7-12.

8. Shapiro RL, Kumar L, Phillips-Howard P, Wells JG, Adcock P, Brooks J, Ackers ML, Ochieng JB, Mintz E, Wahlquist S, Waiyaki P, Slutsker L: Antimicrobial-resistant bacterial diarrhea in rural western Kenya. J Infect Dis 2001, 183(11):1701-4.

9. Gassama A, Sow PS, Fall F, Camara P, Guèye-N'diaye A, Seng R, Samb B, M'Boup S, Aïdara-Kane A: Ordinary and opportunistic enteropathogens associated with diarrhea in Senegalese adults in relation to human immunodeficiency virus serostatus. Int J Infect Dis 2001, 5(4):192-8.

10. Okeke IN, Ojo O, Lamikanra A, Kaper JB: Etiology of acute diarrhea in adults southeastern Nigeria. J Clin Microbiol 2003, 41:4525-4530.

11. Guerrant RL, Hughes JM, Lima NL, Crane J: Diarrhea in developed and developing countries: magnitude, special settings, and etiologies. Rev Infect Dis 1990, 12(Suppl 1):S41-50.

12. Thapar N, Sanderson IR: Diarrhoea in children: an interface between developing and developed countries. Lancet 2004, 363(9409):641-53.

13. Gassama-Sow A, Sow PS, Guèye M, Guèye Ndiaye A, Perret JL, M'Boup S, Aïdara-Kane A: Characterization of pathogenic Escherichia coli in human Immunodeficiency virus-related diarrhea in Senegal. Int J Infect Dis 2004, 189:75-8.

14. Bennett S, Harvala H, Witteveldt J, Leitch ECMW, McLeish N, Templeton K, Gunson R, Carman WF, Simmonds P: Rapid simultaneous detection of enterovirus and parechovirus RNAs in clinical samples by one-step real-time reverse transcription-PCR assay. J Clin Microbiol 2011, 49(7):2620-2624.

15. Ihaka $R$, Gentleman $R: R, A$ language for data analysis and graphics. J Comput Graph Stat 1996, 5:299-314.

16. Brooks JT, Ochieng JB, Kumar L, Okoth G, Shapiro RL, Wells JG, Bird M, Bopp C, Chege W, Beatty ME, Chiller T, Vulule JM, Mintz E, Slutsker L: Surveillance for bacterial diarrhea and antimicrobial resistance in rural western Kenya, 1997-2003. Clin Infect Dis 2006, 43(4):393-401.

17. de Magny GC, Thiaw W, Kumar V, Manga NM, Diop BM, Gueye L, Kamara M, Roche B, Murtugudde R, Colwell RR: Cholera outbreak in Senegal in 2005: was climate a factor? PLoS One 2012, 7(8):e44577.

18. Coker AO, Isokpehi RD, Thomas BN, Amisu KO, Obi CL: Human campylobacteriosis in developing countries. Emerg Infect Dis 2002, 8(3):237-44. 
19. Georges MC, Wachsmuth IK, Meunier DM, Nebout N, Didier F, Siopathis MR, Georges AJ: Parasitic, bacterial, and viral enteric pathogens associated with diarrhea in the Central African Republic. J Clin Microbiol 1984, 19(5):571-5.

20. Bonfiglio G, Simporè J, Pignatelli S, Musumeci S, Solinas ML: Epidemiology of bacterial resistance in gastro-intestinal pathogens in a tropical area. Int J Antimicrob Agents 2002, 20(5):387-9.

21. Kotloff KL, Nataro JP, Blackwelder WC, Nasrin D, Farag TH, Panchalingam S, Wu Y, Sow SO, Sur D, Breiman RF, Faruque AS, Zaidi AK, Saha D, Alonso PL, Tamboura B, Sanogo D, Onwuchekwa U, Manna B, Ramamurthy T, Kanungo S, Ochieng JB, Omore R, Oundo JO, Hossain A, Das SK, Ahmed S, Qureshi S, Quadri F, Adegbola RA, Antonio M, Hossain MJ, Akinsola A, Mandomando I, Nhampossa T, Acácio S, Biswas K, O'Reilly CE, Mintz ED, Berkeley LY, Muhsen $\mathrm{K}$, Sommerfelt H, Robins-Browne RM, Levine MM: Burden and aetiology of diarrhoeal disease in infants and young children in developing countries (the global enteric multicenter study, GEMS): a prospective, case-control study. Lancet 2013, 382(9888):209-22

22. Yongsi HB: Pathogenic microorganisms associated with childhood diarrhea in low-and-middle income countries: case study of Yaoundé Cameroon. Int J Environ Res Public Health 2008, 5(4):213-29.

23. Meurs L, Mbow M, Vereecken K, Menten J, Mboup S, Polman K: Epidemiology of mixed Schistosoma mansoni and Schistosoma haematobium infections in northern Senegal. Int J Parasitol 2012, 42(3):305-11.

24. Randremanana R, Randrianirina F, Gousseff M, Dubois N, Razafindratsimandresy R, Hariniana ER, Garin B, Randriamanantena A, Rakotonirina HC, Ramparany L, Ramarokoto CE, Rakotomanana F, Ratsitorahina M, Rajatonirina S, Talarmin A, Richard V: Case-control study of the etiology of infant diarrheal disease in 14 districts in Madagascar. PLoS One 2012, 7(9):e44533.

25. National Agency of Statistics and Demography: National report of the third census of general population and habitat 2002, Senegal. http://www.ansd.sn/ publications/rapports_enquetes_etudes/enquetes/RGPH3_RAP_NAT.pdf.

doi:10.1186/1471-2334-13-580

Cite this article as: Sambe-Ba et al:: Community-acquired diarrhea among children and adults in urban settings in Senegal: clinical, epidemiological and microbiological aspects. BMC Infectious Diseases 2013 13:580

\section{Submit your next manuscript to BioMed Central and take full advantage of:}

- Convenient online submission

- Thorough peer review

- No space constraints or color figure charges

- Immediate publication on acceptance

- Inclusion in PubMed, CAS, Scopus and Google Scholar

- Research which is freely available for redistribution 